\title{
INITIAL DEVELOPMENT OF ISLAMIC ENVY MANAGEMENT SCALE
}

\section{(IEMS)}

\author{
Sri Nurul Milla \\ Ssekamanya Siraje Abdallah \\ Bakare Kazeem \\ Ahmad Faizuddin \\ Ismail Abdul Fatai \\ Mohamad Tofazzel Hossain \\ Uswatun Hasanah \\ International Islamic University Malaysia \\ Email:sn.milla307@9mail.com
}

\begin{abstract}
Islam discourages the believers fom keeping envious feelings in their hearts. In modern psychology, en $\mid Y$ is Jinked with a group of negative mental health outcomes, such as depression, anxiety, and aggressive behaviors. This study is an attempt to develop a scale $\boldsymbol{q}$ enlp management based on the teaching ofal-Ghazali, one of a Muslim scholar known as Hujjat alIslam, The Proof of Islam. The Benign and Malicious Envy Scale (BeMaSJ developed by Lange \& Crusius (2015) was administered to 200 Muslim students of on Islamic higher learning institution in Malaysia to evaluate their benign and malicious tendencies towards emy. Additionally. the Islamic Eny Management Scale (IEMS) was developed in accordance with alGhazali's proposition on how b eltminate envious feelings among Muslim adults and was administered to the sample. Principal Components Analysis yielded wo factors, namely knowledge and action, with a total variance extracted of 55.5\%. The result.ant scale had a Cronbach Alpha o/O.7. The scale had showed a significant positive correlation with the benign envy and a significant negative correlation with malicious envy.
\end{abstract}

Keywords: envy, Islamic teaching, mental health, PCA.

\section{INTI SARI}

Islam mengajarkan ummatnya untuk tidak menylrnpan rasa lri di dalam hatinya. Dalam kajlan psikologi modern, in hati dihubungkan dengan sejurnlah keadaan emosional yang negatif seperti depresi, kegelisahan, dan perilaku agresif. Kajlan ini bertujuan untuk mengembangkan sebuah instrurnen yang dapat mengevaluasi pengelolaan lri hati dengan merujuk kepada gagasan al- Ghazali, salah satu pemikir Islam yang terkenal dengan julukan Hujjatul Islam. The Benign and Malicious Envy Scale (BeMaS) yang dikembangkan oleh Lange \& Crusius (2015) diberikan kepada 200 mahasiswa Muslim dari sebuah institusi pendidikan tinggi Jslaml di Malaysia. Kemudian, merujuk kepada gagasan al-GhazaU dalam mengelola iri hati, Islamic Envy Management Scale (IEMS) dikembangkan dan disajikan kepada sampel kajian. Berdasarkan basil dari Pricipal Component Analysis, IEMS memiliki dua faktor yaitu ilmu dan arnal dengan total varians 55.5\%. IEMS memiliki nilai Cronbach alpha 0.7. IEMS menunjukkan hasil korelasi positif yang signifikan terhadap beningn envy dan korelasi negatifyang signifikan terhadap malicious envy.

Kata kunci : rasa iri, pengajaran Islam, kesehatan mental, PCA. 
$\mathrm{S}$ cott Peck (1993) highlighted that most of patients" complaint is that the psychiatrists did not pay attention to the spiritual aspect of the patients. When the patients start to inform their spiritual experiences, the psychiatrists shut them down and attempt to divert the conversation to more routine matters. Additionally, the psychiatrists tend to depreciate the spiritual life of the patients. In other words, many psychiatrists have ignored the spiritual aspect of the patients. However, this ignorance has led to five broad areas of failure: occasional, devastating misdiagnosis; frequent mistreatment; an increasingly poor reputation; inadequate research and theory; and a limitation of psychiatrists" own personal development.

Moreover, to avoid the misdiagnosis and mistreatment, there is an important to concern on the spiritual aspect of the patients. Additionally, prior to diagnose and provide the appropriate intervention, the psychiatrists need to collect the sufficient information of the patients. One of the ways of data collection is administering the assessment.

Focusing on the Muslims society who have different culture with the westerns, Badri (1979) emphasizes that the Muslims psychiatrists should not adopt the measurement developed by the western psychologists as it might lead to the invalid result (Badri, 1979). Therefore, there is a need to develop an Islamic based assessment to be administered to the Muslims.

This study aims to develop the Islamic based assessment to investigate the extent to which someone deals with his/ her envious feeling. Envy has been defined in numerous ways by different authors. it is seen as the feeling unhappy when others enjoy superior advantage than the person who envies (Salovey \& Rodin, 1991). it is described as nursing hostility and ill will against an individual who is blessed (Parrot, 1991). Envy is regarded as an unpleasant emotion which arises when an individual compare him/herself not favorably blessed with others (Smith \& $\mathrm{Kim}, 2007$ ). in islamic perspective, envy (hasad) is described as the condition where one feels sad with others" fortunes and feels good with their misfortunes as revealed in the Quran Surah At Taubah verse 50 that:

"If good befalls thee, it grieves them; but if a misfortune befalls thee, they say, "We took indeed our precautions beforehand," and they turn away rejoicing." (QS. At -Taubah: 50).

\section{Benign and Malicious Envy}

The Quran has documented a number of crime stories caused by envy. The first murder occurred by a human being named Qabil, the son of Prophet Adam, was led by an envious feeling. It is revealed in the Quran in Surah Al Maldah:

"Recite to them the truth of the story of the two sons of Adam. Behold! They each presented a sacrifice (to Allah): it was accepted from one, but not from the other. Said the latter: "Be sure I will slay thee." "Surely," said the former, "(Allah) doth accept of the sacrifice of those who are righteous. "(QS. AL Moidah: $Z 7$ )

Another case of envy is the story of Prophet Yusuf. He was envied by his siblings as they perceived that their father loved Yusuf more than them. Therefore, they did harm to Yusuf by pushing him into a well. Allah SWT revealed in the Quran:

"They said: "Truly Yusuf and his brother are loved more by our father than we: But we are a goodly body! Really our father is obviously in error!" Slay ye Yusuf or cast him out to some (unknown) land, that so the 
finvour of your fiather my be given to you alone: (there will be time enough) for you to be righteous after that! Said one of them: "Slity not Yusuf, but if ye must do something, throw him down to the bottom of the well: he will be picked up by some cariavan of tr avellers." (QS. Yusuf: 8)

Initially envy is seen something negative. Salovey and Rodin (1986) highlighted that envy comprises negative emotion such as hostility, inferiority, hate, resentment, guilt, anger and anxiety. That is why Smith and Kim (2007) suggests that envy humiliates and annoys people; equally envy is one of the most socially disgusting emotions, and can be destructive for both groups and the individual in organizational outcomes, for example in situations where malicious gossip allows flowing (Wert \& Salovey, 2004). Reviewing the previous studies on envy, Smith \& Kim (2007) defines envy as "an unpleasant, often painful emotion characterized by feelings of inferiority, hostility, and resentment produced by an awareness of another person or group of persons who enjoy a desired possession". Envy is usually activated by making social comparisons with advantaged others in domains of personal relevance (Hill, DelPriore \& Vaughan, 2011).

Envy is associated with a lot of mental health problems such as depression, sadness and neuroticism (Rebecca, 2014) Even study has shown that envy is related to various negative behaviors such as feelings of hostility (Smith, 1991), guilt, inferiority and resentment (Parrott \& Smith, 1993). More so, envy has been linked with more severe forms of maladjustment like depression and anxiety (Salovey \& Rodin, 1984); personality disorders (American Psychiatric Association, 1994). Additionally, Gold (1995) found that envy is correlated with various psychopathologies namely depression, anxiety, and paranoid ideation. Furthermore, characterized by malicious tendencies, envious feeling might lead to misconduct. A comprehensive review of studies on envy documented that envy stimulates to aggressive behaviors such as publicized crimes, assassination, murder, and sabotage (Smith \& Kim, 2007).

Considering the negative consequences of envy, in a hadith reported by Abu Dawud, it is narrated that Prophet Muhammad SAW has instructed the Muslims to avoid envy as it will consume the good deeds as well as the fire that easily burns the woods. In other words, envy has to be eliminated as it will lead to destruction. However, as narrated by Abdullah lbn Masud, the Prophet Muhammad SAW said that Muslim should envy two the types of people as it can motivate the envier to perform the same actions like they did. These people are the one who spends all the wealth Allah gave him on the path of righteousness, and the other is the person who judges with the knowledge Allah gave him and teaches it to others (Buhari, Ilim 15). Therefore, Islam recognizes two types of envy; the negative and positive.

Likewise, despite the negative outcomes connected with envy, previous studies also found that there are positive aspects of envy. For instance (Gold, 1996) posits that envy has occasionally seen as a pleasing trait due to the premise that it could serve as the basis for achievement when it motivates a high degree of effort to attempt to acquire the desired object. Equally according to the study of Hill and Buss (2008), envy has offered selective advantages for survival and reproduction in competitive socio-economic environments characterized by scarce resources. Envy could alert us to being outperformed by other people and to motivate us to level these differences or even surpass our 
competitors (Crusius \& Lange, 2014). In addition, it has been argued that the pain we go through when being envious propeis us to mitigate the damaging effects of threatening social comparisons on our selfesteem, its maintenance being a fundamental human need (Tesser, 1988). Equally, Vende Ven, Zeelenberg, and Pieters, (2009) articulated more positive views on envy, by describing it as benign, admiring, and emulative. Meaning that, there are positive sides of envy. What can be concluded from the literatures is that there is both positive and negative aspect of envy.

Meanwhile, it has been understood from past studies that envy might elicit two contrasting outcomes which might be positive or negative. Based on this, positive aspect of envy in termed as benign envy, while the negative envy is termed as malicious envy. Benign envy is describes as the type that drives individuals to improve their condition and motivates them to reach the desired outcome. When experiencing benign envy, individuals aim to pull themselves closer to the envied, resulting in experiences of moving-up motivation (Rebecca, 2014). Benign envy is characterized by an admiration of others, emulation, level up, actionable, upward mobility and unlimited (Belk, 2011). Benign envy increases the motivation to invest more effort to improve one "s own position (Lange \& Crusius, 2015).

On the other hand the second type of envy is malicious envy which is described as being associated with frustration and the desire for the fortune to be stripped from the envied (Smith \& Kim, (2007). malicious envy is seen as something linked with negative outcomes alone (van de Ven et al., 2009) even malicious envy leads to a pulling-down motivation aimed at damaging the position of the superior other (van de Ven, Zeelenberg, \& Pieters, 2009). Equally Smith and Kim, (2007) posit that malicious envy share resemblance with resentment.

Nevertheless, it was argued by (Smith \& Kim, 2007) that envy does not have any positive outcome because it is seen as negative emotion. It was pointed out that the usage of the word envy are pronounced in two contradictory ways which are "envy proper" and benign envy. It was opined that benign envy is something close to admiration and the envy proper is negative emotion as reported by (Smith \& Kim, 2007).

What can be deduced here is that envy originaliy is negative emotion which elicits malicious feeling which is characterized with resentment, hatred, jealous and evil thought against others. However these ill feelings can be redirected towards fruitful and desirable outcomes. Meanwhile, this act of redirection involves systematic application of some procedures. Based on this, the present research proposed to create an Islamic based scale which could serve as a means of systematic redirection of the malicious envy to benign envy which could elicit positive and desirable outcomes.

\section{Ghazali's proposition on managing envy}

Al-Ghazali in one of his greatest works, thyo "Ulumuddin, warned about envy. He wrote the third quarter of his book on destructive matters of life. It comprises ten books in which Al-Ghazali wrote a number of pages on the condemnation of anger, rancour and envy and their dangers.

According to Al-Ghazali, envy is one of the deadliest diseases of the hearts. Under all circumstances, envy is unlawful. In matters of envy, there is no distinction between Muslims and non- Muslims. Everyone is the same.

Allah SWT states in the Qur"an, "If good befalls you, it distresses them; but if disaster strikes you, they say, "We took our 
matter [in hand] before," and turn away while they are rejoicing" (Q.S. At- Tawbah, 9: 50).

According to the status, Al-Ghazali mentioned that there are three stages of envy:

1. The envious person loves that wealth and gifts should go away from the person envied and they should not come to him again;

2. The envious person wishes to have the gifts of the envied person; and

3. The envious person does not wish to have identical things for himself but to have similarthings.

These stages are slightly different in nature. The first stage is unlawful and the worst condition. The second one is lawful but not commendable. And the third stage is condemned in some cases and not in others.

In his book Al-Ghazali revealed seven causes of envy started from the worst one. They are 1) enmity, 2) Dislike of another"s good, 3) Pride, 4) To express wonder, 5] Fear of failure of object, 6 ) Greed of name and power, and 7 ) Narrowness of mind. Based on the list, it is clear that the root cause of envy is the love of the world. Only true religious person can manage their envy well.

Ghazali proposes two ways to cure envy. They are through knowledge and action. To treat envy through the knowledge, a person should learn and know without any doubt that envy is deadly for his life and religion. $\mathrm{He}$, for example, might hate and object Allah"s predestination, His justice and wisdom which are shared among alt mankind. In this regards, to envy is to express displeasure at the distribution of God. Whenever an envier sees the blessings of Allah upon the envied ones, he will be suffered and tortured. The poisonous envy consumes good deeds of a person and erases them like the night erases the day.
To treat envy through the action, a person should control himself and strive to do the opposite. If for example, envy drives the envier to say bad things about the envied person, then he should strive to control his tongue and complement him instead; if it drives the envier to look down upon the envied person, then he should strive to act with humility and apologize to him; and if envy drives the envier to stop doing good things for the envied person, then he should strive to force himself doing things for him.

\section{METHOD}

This study is conducted using a quantitative method. Creswell (2009) conceptualizes a quantitative approach as a predetermined study through which "the researcher tests a theory by specifying narrow hypotheses and the collection of data to support or refute the hypotheses" (p.16).

The researchers selected 200 Muslim students of an Islamic higher learning institution in Malaysia as the respondents. The sample was purposively selected as they fulfilled the required criteria for this study which are Muslim adults and having been attended an either formal or informal Islamic class.

The data of this study were collected through a survey. Creswell (2009) suggested that a survey technique provides the number based explanation to describe a trend, attitude, or opinion from the sample. Furthermore, in order to understand the extent to which applying Islamic teaching can help someone in managing their envious feeling, a set of questionnaire were distributed to the sample. The questionnaire consists of demographic information, the Benign and Malicious Scale (BeMaS), and the Islamic Envy Management Scale (IEMS).

The Benign and Malicious Scale 
(BeMaS) was developed by Lange and Crucius (2015). The scale consists of 10 items with a six-point Likert - scale concerning on the motivational consequences of envy. However, in this study, the respondents are required to indicate on a five-point Likert - scale the extent to which the statement describes them. Five of the 10 items belongs to benign motivational consequences of envy and the other five items are the malicious motivational consequences.

Islamic Envy Management Scale (IEMS) is an Islamic based scale on managing envy, particularly the one proposed by Al - Ghazali. At the first phase, IEMS consists of 12 items with a five point Likert - scale the extent to which the respondents apply the proposition described in the items.

The data were further analyzed using the SPSS (Statistical Package for the Social Science) soltware. At the first step, the principle component analysis (PCA) was conducted to group the items. The reliability coefficient was further tested. Lastly, the Pearson correlation test was performed to examine the correlation of IEMS and BeMaS subscales as well as the correlation of IEMS"s subscales and the BeMas"s subscale.

\section{RESULT}

\section{Demographic Background}

The respondents for this study consisted of 200 students. They were classified according to gender, educational background and nationality. Fifty-four percent $(n=10 B)$ of the respondents are female and forty-six percent $(n=92)$ are male. Majorities (63.5\%) are undergraduate students, and the rest (36.5\%) are postgraduate students. The average age of the respondents is 24 years old. With regards to respondents' nationality, there were twenty-three different nationalities participated in the survey. Malaysians constituted more than half $(56.5 \%)$ of the total respondents, followed by Indonesia, Nigeria, and Bangladesh with $8 \%, 4.2 \%$ and $4 \%$ respectively.

\section{The Development of IEMS}

Envy has been acknowledged for its motivational consequences in human behavior. Studies have emphasized ma licious tendencies on envy (e.g. Salovey \& Rodin, 1986; Smith \& Kim, 2007; Wert \& Salovey, 2004)). However, in certain circumstances, the benign significances of envy are recognized. Therefore, there might be a possibilty of managing the envious feeling to have more positive tendencies. In other words, envy management through motivational consequences will result in benign values.

Furthermore, generating the items from Al - Ghazali"s proposition on managing envy, IEMS is developed as an Islamic based assessment on managing envy. In the first stage, IEMS consisted of 12 items (see table 1). 
Table 1. The Items of Islamic Envy Management Scale

\begin{tabular}{l} 
No. \\
\hline 1. When someone has or can do something better than me, I praise them. \\
2. When others get something good, I express my happiness for them. \\
3. When another person has a good quality that I don "t have, I do not show \\
my humility to them. (reverse code) \\
4. When I envy others, I verbally express my envious feeling to them. \\
(reverse code) \\
5. I blame my soul for envying others. \\
6. When I envy someone, I talk about his/ her with my friend. (reverse code) \\
7. Knowing the punishment in the hereafter does not stop me from feeling \\
8. I amvious. (reverse code) \\
9. Whe to eliminate my envious f geling because I know that God is the \\
10. When I envy someone better than me, I compare myself with someone \\
Inf erior to eliminate my envious feeling. \\
11. Feeling envious makes me suff er for nothing. \\
12. When I envy others, I remember what God has given to me.
\end{tabular}

Principle Component Analysis of IEMS

Based on the rotated component matrix of IEMS, the items of IEMS are grouped into two factors; knowledge and action.

Table 2. Rotated Component Matrix of IEMS

\begin{tabular}{|c|c|c|c|c|}
\hline \multirow{2}{*}{ No } & \multirow{2}{*}{ Items } & \multicolumn{2}{|c|}{ Component } & \multirow{2}{*}{$\begin{array}{c}\text { Name of the } \\
\text { factor }\end{array}$} \\
\hline & & 1 & 2 & \\
\hline K1 & $\begin{array}{l}\text { When I envy others, I remember what God } \\
\text { has given to me. }\end{array}$ & .843 & & Knowledge \\
\hline $\mathrm{K} 2$ & $\begin{array}{l}\text { I am able to eliminate my envious feeling } \\
\text { because I know that God is the one who } \\
\text { gives and takes. }\end{array}$ & .745 & & \\
\hline K3 & $\begin{array}{l}\text { When I think about the punishment in the } \\
\text { hereafter, I regret envying others. }\end{array}$ & .717 & & \\
\hline K4 & $\begin{array}{l}\text { When I envy someone better than me, } 1 \\
\text { compare myself with someone inf erior to } \\
\text { eliminate my envious feeling. }\end{array}$ & .552 & & \\
\hline A1 & $\begin{array}{l}\text { When others get something good, I express } \\
\text { my happiness for them. }\end{array}$ & & .848 & Action \\
\hline A2 & $\begin{array}{l}\text { When someone has or can do something } \\
\text { better than me, I praise them. }\end{array}$ & & .854 & \\
\hline A3 & I blame my soul for envying others. & & .509 & \\
\hline
\end{tabular}




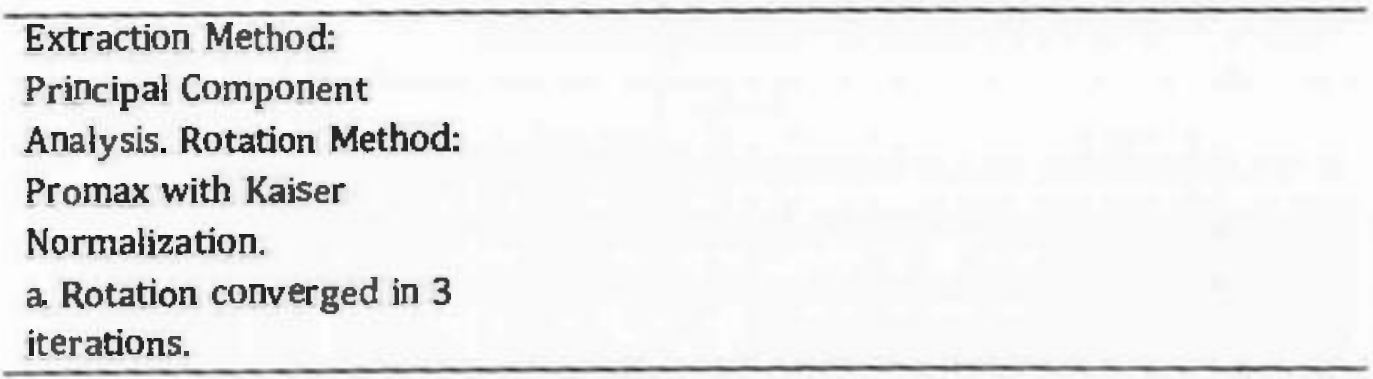

The knowledge factor consists of 4 items: (knowledge 1) when I envy others, I remember what God has given to me, (knowledge 2) I am able to eliminate my envious feeling because 1 know that God is the one who gives and takes, (knowledge 3) when 1 think about the punishment in the hereafter, I regret envying others and (knowledge 4) when I envy someone better than me, I compare myself with someone inferior to eliminate my envious feeling. The action factor consists of 3 items: (action 1) when others get something good, I express my happiness for them, (action 2) when someone has or can do something better than me, I praise them, and (action 3) I blame my soul for envying others.

Further, the total variance explained of IEMS shows that all the factors have the Eigen values more than 1 (see table 3) suggesting that the two factors need to be retained, Knowledge contributes to $37 \%$ of the variance, while action contributes to $18 \%$ variance to scale. The total variance extracted from the accumulation of both factors is $55.5 \%$. Hair et al. (1995) emphasized that in the social sciences, the total variance extracted is normally as low as $50-60 \%$.

Table 3. Total Variance Explained of IEMS

\begin{tabular}{cccc}
\hline Factor & Eigen Value & \% of Variance & $\begin{array}{c}\text { Total variances } \\
\text { extracted }\end{array}$ \\
\hline Knowledge & 2.617 & 37.380 & 37.380 \\
Action & 1.271 & 18.156 & 55.535 \\
\hline
\end{tabular}

\section{Reliability of IEMS}

The internal consistency alpha coefficient for each factor of IEM S was then tested. The internal consistency alpha coefficient for each scale and sub-scale indicates a relatively adequate internal consistency of the items measuring each construct The alpha coefficient which is more than 0.6 indicates the sufficient internał reliability (Nunnally, 1978).

Table 4. Reliability Statistic of the IEMS, BeMaS, and Their Subscales

\begin{tabular}{cccc}
\hline Scale & Subscale & $\begin{array}{c}\text { Cronbach's } \\
\text { Alpha }\end{array}$ & $\begin{array}{c}\text { N of } \\
\text { Items }\end{array}$ \\
\hline IEMS & Knowiedge & .709 & 7 \\
& Action & .693 & 4 \\
BeMaS & Benign & .618 & 3 \\
& Malicious & .680 & 10 \\
& & .725 & 5 \\
\hline
\end{tabular}


In general, the reliability for each scale indicates a high internal consistency of the items with Cronbach alpha 0.725 for envy benign, 0.734 for envy malicious and 0.709 for IEMS. This shows that the entire scales were robust for the sample size and the participant. The scale has adequate reliability for exploratory research (Pett,
Lackey, \& Sullivan, 2003). To check the correlation among the IEMS subscales, Pearson correlation test was performed between knowledge and action factor (see table 5). The analysis shows that the two factors is significantly correlated ( $r=$ $0.328, \mathrm{p}<0.01$ ).

Table 5. Correlation analysis among IEMS subscale

\begin{tabular}{lll}
\hline & & Action \\
\hline Knowledge & Pearson Correlation & $0,328^{* * *}$ \\
& Sig. (2-tailed) & 0,000 \\
& $\mathrm{~N}$ & 200 \\
\hline
\end{tabular}

Moreover, IEMS consisting of 7 items is considered as statistically reliable to measure how people manage their envious feeling. The remaining items of IEMS are as follow:

Table 6. Resultant IEMS

\begin{tabular}{|c|c|}
\hline Factor & Items \\
\hline Knowledge 1 & When I envy others, I remember what God has given to me. \\
\hline Knowledge 2 & $\begin{array}{l}\text { I am able to eliminate my envious feeling because I know that God } \\
\text { is the one who gives and takes. }\end{array}$ \\
\hline Knowledge 3 & $\begin{array}{l}\text { When l think about the punishment in the hereafter, I } \\
\text { regret envying others. }\end{array}$ \\
\hline Knowledge 4 & $\begin{array}{l}\text { When l envy someone better than me, I compare myself with } \\
\text { someone inf erior to eliminate my envious feeling. }\end{array}$ \\
\hline Action 1 & When others get something good, I express my happiness for them. \\
\hline Action 2 & $\begin{array}{l}\text { When someone has or can do something better than me, } 1 \\
\text { praise them. }\end{array}$ \\
\hline Action 3 & I blame my soul for envying others. \\
\hline
\end{tabular}

\section{IEMS and subscales of BeMaS}

As a preliminary study of validating the assessment on managing envy, this study aims to investigate the extent to which IEMS correlates to the benign and malicious envy. For this reason, the Benign and Malicious Envy Scale (BeMaS) developed by Lange \& Crusius (2015) is adopted to assess the tendency of motivational consequences of envy.

The Pearson correlation test documented that IEMS is positively and significantly correlated to Benign subscale of $\mathrm{BeMaS}(\mathrm{r}=.229, \mathrm{p}<0.01)$. [EMS has also a statistically significant negative correlation with the malicious subscale ( $r=$ $-0,194 \mathrm{p}<0.05$ ).

Referring to Cohen"s (1988) proposed correlation ( $r$ ) $=.10$ to .29 (small correlation: both positive and negative correlation), $\mathrm{r}=.30$ to .49 (medium correlation), and $r=. S 0$ to 1.00 (large correlation), it can be easily inferred that the correlation coefficient for IEMS and the 
subscales on BeMaS fell with the range of .104 and 0.256 , which can be classified based on Cohen"s as small correlation (Table 7). As a result, it is evident that the pair " $F$. Knowledge" and "F. benign" exhibits the highest correlation coefficient of $r=0.256(p<0.01)$.

Table 7. EMS and subscales of BeMaS

\begin{tabular}{cccc}
\hline & & F. Benjgn & F. Malicious \\
\hline IEMS & Pearson Correlation & $.229^{* * *}$ & $-.194^{*}$ \\
& Sig. (2-tailed) & .001 & .015 \\
\hline F. Knowledge & Pearson Correlation & $.256^{* * *}$ & $-.183^{*}$ \\
& Sig. (2-tailed) & .000 & .029 \\
\hline F. Action & Pearson Correlation & .104 & -.128 \\
& Sig. (2-tailed) & .143 & .071 \\
\hline N =200 & & \\
$* *$ Correlation is significant at the 0.01 level (2-tailed). & \\
*. Correlation is significant at the 0.05 level (2-tailed).
\end{tabular}

\section{DISCUSSION}

In line with al-Ghazali"s teaching on managing envy, the resultant IEMS suggests that there are four important things to know concerning envy. First, a Muslim must express his/ her gratitude towards Allah SWT by remembering what He has given to him/ her. Remembering Allah is the source to comfort and calm the heart so that there will be no unease feeling toward others" fortune.

Second, it needs to be understood that Allah SWT is the one who gives and takes every single thing in this life. Believing Allah"s decision (Qadar), a Muslim should not keep his envious feeling and having malicious tendencies towards the envied person as Allah SWT revealed in the Quran:

"And in no wise covet those things in which Allah Hath bestowed His gifts More freely on some of you than on others: To men is allotted what they earn, and to women what they earn: But ask Allah of His bounty. For Allah hath full knowled ge of all things." $(Q S$. An Nisa: 32)
The third important thing to know is that Muslim supposes to regret his/ her malicious envious feeling since envy leads to a punishment in the hereafter. Furthermore, when the envious feeling comes, it is required for the Muslim to compare himself with someone inferior.

Furthermore, a Muslim should implement his knowledge on envy to his action. The scale highlights three actions to be performed by a Muslim when he having an envious feeling. First, he/ she must express the happiness to others who get something good. Further, when someone has or can do something better than him/her, it is suggested to praise that person. Lastly, a Muslim should hate his/ her soul for envying others.

Through this scale, it can be assessed how someone particularly a Muslim deals with his/ her envious feeling. This information might be useful for the psychiatrist or counselor to diagnose the problem of the patient/ client so that the appropriate intervention can be suggested and implemented to help him/ her to reduce his/ her enviousness. 


\section{CONCLUSSION}

Taking into serious consideration the hostility and destruction of envious feeling towards individuals and societies" mental well-being, the need of managing this feeling is vital. Inability to manage envy can lead to many mental health problems such as anxiety, hatred and even depression. With the notion of negative consequences of envy to individuals" mental well-being as well as their spiritual growth calls for proper management. However this attempt may not be achieved without having proper knowledge how to manage the subject.

The envy management which includes its treatment only can be developed appropriately by taking many aspects into consideration. To have treatment that can fit into target group or society at large, the management should start from the assessment that evaluates the aspects which matter to the target group or society such culture, value, spiritual state, etc. As an islamic based assessment, IEMS might be considered as a reliable assessment in evaluating on how someone particularly a Muslim manages their envious feeling and thus the proper int ervention can be provided.

\section{RECOMMENDATION}

Based on the result of this study, there is a need to conduct further studies on validating the IEMS using the different tools such as SEM (Structural Equation Modeling) and Rash model. Additionally. the bigger sample size is required, withm minimum 200 sample size for SEM data analysis.

\section{REFERENCES}

Al-Ghazzali, M. B. (nd). Ihyo "Ulumuddin (The Revival of Religious Sciences)
(Volume 3). Beirut: Dar lhya alKutub al-, IImiyyah.

American Psychiatric Association. (1994). Diagnostic and statistical manual of mental disorders (Ath edn). Washington, DC.

Badri, M. (1979). The Dilemma of Muslim psychologists. London: WMH London Publishers. Belk, R. (2001). Benign envy.AMS Review, 1, 117 -134.

Chong. R. J. (2014). Emy across the lifespan. Published master thesis. Carolina.

Cohen, J. (1988). Statistical power analysis for the behovioral sciences ( $2^{\text {nd }} \mathrm{ed}$ ). Hillsdale, Nj: Lawrence Earlbaum Associates.

Creswell, John W. (2009). Research design: Qualitative, Quantitative, and Mixed Methods Approaches 3ed. California: Sage Publication inc.

Crusius, j., \& Lange, j. (2014). What Catches the envious eye? Attentional biases within malicious and benign envy. Journal of Experimental Social Psychology, 55, 1-11.

Gold, B. T. (1996). Enviousness and its relationship to maladjustment and psychopathology. Personality and Individual Differences, 21(3), 311321.

Hair, J., Anderson, R. A, Tatham, R L, Black, W. C. (1995). Multivariate dato analysis. $4^{\text {th }}$ ed. Jersey: Prentice-Hall Inc.

Hill, S, E, \& Buss, D. M. (2008). The evolutionary psychology of envy. in 
R. H. Smith (Ed.), Envy: Theory and research (pp. 60-70). New York: Oxford University Press.

Lange, J, \& Crusius, J. (2015). Dispositional envy revisited: Unraveling the motivational dynamics of benign and malicious envy. Personality and Social Psychology Bulletin, 41 (2), 284-294.

Nunnally, J. C. (1978). Psychometric theory. New York: Mc Graw-Hill.

Peck, M. S. (1979). Further Along the Road Less Traveled. New York: Simon \& Schuster.

Parrott, W. G., \& Smith, R. H. (1993). Distinguishing the experiences of envy and jealousy. Journal of Personality and Social Psychology, 64 (6), 906-920.

Pett, M., Lackey, N. \& Sullivan, J. (2003). Making sense of factor analysis. Thousand Oaks: Sage Publications, Inc.

Salovey, P. (1991). Social comparison processes in envy and jealousy. In J. Suls \& T. AshbyWills (Eds.). Sociol Comparison Contemporary Theory and Reseorch (pp. 261-285), Hillsdale, N], England: Lawrence Erlbaum Associates, Inc.

Salovey, P. \& Rodin, J. (1986). The differentiation of social-comparison jealousy and romantic jealousy. Journal of Personality and Social Psychology, 50 (6), 1100-1112.

Smith, R H (1991). Envy and the sense of injustice. In $P$. Salovey (Ed.), Psychologicol perspectives on jealousy and envy (pp. 79-99). New York: Guilford.

Smith, R. H., \& Kim, S. H. (2007). Comprehending envy. Psychological Bulletin, 133(1), 46-64.

Tesser, A. (1988). Toward a self-evaluation maintenance model of social behavior. In L. Berkowitz (Ed.), Advances in experimental social psychology (Vd. 21, pp. 181-227). San Diego, CA: Academic Press.

The Presidency of Islamic Researches, IPTA, Call and Guidance (eds). (n.d). The Holy Quran: English transiation of the meanings and commentary.

Van de Ven, N., Zeelenberg, M., \& Pieters, R. (2009). Leveling up and down: the experiences of benign and malicious envy. Emotion (Washington, DC.), 9(3), 419-429.

Wert, S. R, \& Salovey, P. (2004). A social comparison account of gossip. Review of General Psychology, 8, 122137. 